\title{
The Application of The Quantum Teaching Model in Improving Mathematical Learning Motivation in Grade Iv Students of SD Negeri 2 Kertodeso in Academic Year 2018/2019
}

\author{
Susilailiy Rahmawati ${ }^{1}$, Joharman ${ }^{2}$, Rokhmaniyah ${ }^{3}$ \\ 1,2,3 Universitas Sebelas Maret \\ susilaili25@gmail.com
}

\section{Article History}

accepted 01/06/2019

\begin{abstract}
This study aimed to describe the application of quantum teaching models and describe the increase in students' mathematics learning motivation through the application of quantum teaching models. This study used classroom action research (CAR) with a type of collaborative research. The data collection instruments used were observation sheets, interview guidelines, questionnaires and document study sheets. The results of this study indicated that the application of the quantum teaching model was carried out by the following steps: (a) growing, (b) experiencing, (c) naming, (d) demonstrating, (e) repeating, and (f) celebrating. The application of the quantum teaching model could increase the motivation to learn mathematics in fourth grade students of SDN 2 Kertodeso in Academic Year 2018/2019. This is evidenced by an increase in the average observation results and questionnaires of students' mathematics learning motivation in each cycle. The average observation motivation of learning in the first cycle was $72.08 \%$, in the second cycle was $85.83 \%$, and in the third cycle, it increased to $90.00 \%$. The average students' learning motivation questionnaire in the first cycle was $74.50 \%$, in the second cycle was $85.18 \%$, and in the third cycle, it increased to $90.42 \%$.
\end{abstract}

Keywords: quantum teaching, learning motivation, mathematics

\section{Abstrak}

Penelitian ini bertujuan untuk mendeskripsikan penerapan model pengajaran kuantum dan mendeskripsikan peningkatan motivasi belajar matematika siswa melalui penerapan model pengajaran kuantum. Penelitian ini menggunakan penelitian tindakan kelas (PTK) dengan jenis penelitian kolaboratif. Instrumen pengumpulan data yang digunakan adalah lembar observasi, pedoman wawancara, kuesioner dan lembar studi dokumen. Hasil penelitian ini menunjukkan bahwa penerapan model pengajaran kuantum dilakukan oleh langkah-langkah berikut: (a) tumbuh, (b) mengalami, (c) penamaan, (d) menunjukkan, (e) mengulang, dan (f) merayakan. Penerapan model pengajaran kuantum dapat meningkatkan motivasi belajar matematika pada siswa kelas empat SDN 2 Kertodeso pada Tahun Akademik 2018/2019. Hal ini dibuktikan dengan peningkatan hasil observasi rata-rata dan angket motivasi belajar matematika siswa pada setiap siklusnya. Motivasi observasi rata-rata belajar pada siklus pertama adalah $72,08 \%$, pada siklus kedua adalah 85,83\%, dan pada siklus ketiga, meningkat menjadi $90,00 \%$. Kuesioner motivasi belajar rata-rata siswa pada siklus pertama adalah $74,50 \%$, pada siklus kedua adalah $85,18 \%$, dan pada siklus ketiga, meningkat menjadi $90,42 \%$.

Kata kunci: pengajaran kuantum, motivasi belajar, matematika 


\section{PENDAHULUAN}

Matematika merupakan ilmu yang sangat mendasar. Matematika membekali siswa agar memiliki kemampuan analitis, berpikir logis, sistematis, kritis dan kreatif. Namun ternyata masih banyak siswa yang mengangggap matematika itu sulit. Sebagian besar siswa merasa takut untuk belajar matematika. Menurut Nurhartiningrum dan Zuli (2018: 394), belajar matematika perlu adanya sikap kreatif pada diri siswa, namun ternyata masih banyak faktor yang menyebabkan siswa merasa jenuh dan bosan dalam belajar matematika. Kebosanan tersebut dapat mengakibatkan siswa tidak tertarik untuk belajar matematika. Dalam hal ini, guru perlu melaksanakan pembelajaran yang menyenangkan dan kreatif agar siswa tidak merasa bosan. Kewajiban guru untuk melaksanakan pembelajaran yang menyenangkan dan kreatif diatur dalam UU RI No. 20 pasal 40 ayat (2a) tahun 2013 tentang Sisdiknas yang berbunyi: "Guru dan tenaga kependidikan berkewajiban: a. Menciptakan suasana pendidikan yang bermakna, menyenangkan, kreatif, dinamis, dan dialogis." (Sunarto, 2012: 11).

Kondisi nyata yang peneliti temui di sekolah dasar yaitu pembelajaran matematika dirasa masih membosankan, siswa kurang antusias dalam mengikuti pembelajaran dan motivasi belajar yang masih rendah. Setelah peneliti melakukan observasi dan wawancara dengan guru kelas IV SD Negeri Kertodeso pada hari Sabtu tanggal 3 November 2018, diketahui bahwa rata-rata hasil Ulangan Tengah Semester (UTS) matematika siswa kelas IV masih cukup rendah yaitu 66,8 dari batas Kriteria Ketuntasan Minimal (KKM) sebesar 70. Berdasarkan data yang diperoleh, diketahui bahwa dari siswa yang berjumlah 24 orang, ada 12 atau $50 \%$ siswa yang sudah memenuhi KKM dan ada 12 atau 50\% siswa yang belum memenuhi KKM. Hal tersebut menunjukkan bahwa sebenarnya siswa mampu untuk mendapatkan nilai di atas KKM sehingga perlu dikembangkan pembelajaran yang menyenangkan agar siswa termotivasi untuk mengikuti pembelajaran matematika.

Berdasarkan data tersebut, maka guru sebagai seorang pendidik harus mampu menciptakan suasana yang menyenangkan agar siswa memiliki motivasi dalam belajar dan tujuan pembelajaran pun dapat tercapai.

Motivasi adalah perubahan energi yang terjadi dalam diri seseorang yang ditandai dengan timbulnya perasaan dengan adanya reaksi-reaksi untuk mencapai tujuan. Tujuan motivasi dalam hal ini adalah tujuan pembelajaran itu sendiri. Menurut Awofala \& Falolu (2017: 372) "motivation is the internal state that arouses, directs, and sustains goal-oriented behaviour". Artinya "motivasi adalah keadaan internal yang membangkitkan, mengarahkan, dan mempertahankan yang berorientasi pada tujuan". Salah satu cara yang dapat ditempuh guru adalah dengan menyajikan atau memilih model atau metode pembelajaran yang membuat siswa gembira saat pembelajaran berlangsung (Hamalik, 2015: 158). Darmasnyah (Sunarto, 2012: 4) menyatakan bahwa hasil penelitian dalam dekade terakhir mengungkapkan bahwa belajar akan lebih efektif, jika siswa dalam keadaan gembira. Kegiatan yang dapat membuat siswa gembira dapat diwujudkan dengan penerapan model Quantum Teaching. Hal ini sesuai dengan pendapat Saud (Rusman, 2014: 329) yang menyatakan bahwa terdapat beberapa model pembelajaran yang dapat mendukung pembelajaran yang aktif, efektif, dan menyenangkan salah satu diantaranya yaitu pembelajaran kuantum.

Quantum Teaching adalah penggubahan belajar yang meriah, dengan segala nuasanya (Shoimin, 2014: 138). Model quantum teching menyajikan kegiatan-kegiatan yang menyenangkan dalam pembelajaran sehingga siswa termotivasi untuk belajar. DePorter, Reardon dan Singer-Nourie (2011: 34) mengungkapkan bahwa Quantum Teaching adalah penggubahan berbagai interaksi yang ada di dalam atau di sekitar momen belajar. Interaksi tersebut mencakup unsur-unsur untuk belajar efektif yang mempengaruhi kesuksesan siswa. Dalam peneltiannya, Yahya (2017: 159) menggunakan kerangka rancangan quantum teaching yaitu TANDUR, adalah 
singkatan dari Tumbuhkan, Alami, Namai, Demonstrasi, Ulangi dan Rayakan untuk diterapkan dalam langkah-langkah pembelajaran.

Berdasarkan uraian tersebut, peneliti tertarik untuk melakukan penelitian tentang penerapan model Quantum Teaching pada pembelajaran matematika agar siswa termotivasi untuk belajar matematika. Peneliti menggunakan judul penelitian yaitu "Penerapan Model Quantum Teaching dalam Peningkatan Motivasi Belajar Matematika Siswa Kelas IV SD Negeri 2 Kertodeso Tahun Ajaran 2018/2019."

\section{METODE}

Pendekatan penelitian yang digunakan dalam penelitian ini adalah penelitian tindakan kelas. Jenis penelitian yang digunakan adalah penelitian kolaboratif atau kerjasama antara guru kelas IV SD Negeri 2 Kertodeso dengan peneliti. Subjek penelitian ini adalah seluruh siswa kelas IV SD Negeri 2 Kertodeso tahun ajaran 2018/2018 yang berjumlah 24 siswa, yang terdiri dari 12 siswa laki-laki dan 12 siswa perempuan dan guru kelas IV. Data pada penelitian ini berupa data kualitattif dan data kuantitatif. Data kualitatif berupa informasi mengenai pelaksanaan pembelajaran matematika dengan model Quantum Teaching, sedangkan data kuantitafif berupa motivasi belajar matematika. Teknik pengumpulan data menggunakan observasi, wawancara, angket dan tes. Uji validitas data menggunakan triangulasi teknik dan sumber. Validitas isi menggunkan kisi-kisi. Analisis data meliputi reduksi data, penyajian data, dan kesimpulan sesuai model analisis data menurut Miles dan Huberman (Sugiyono, 2013: 337). Indikator kinerja penelitian ini adalah pelaksanaan langkah-langkah penerapan model Quantum Teaching dan peningkatan motivasi belajar matematika siswa dengan kecapaian target 85\%. Penelitian ini menggunakan prosedur penelitian Kemmis dan Taggart (Arikunto, 2013: 137), yaitu terdiri dari tahap perencanaan, pelaksanaan, pengamatan, dan refleksi.

\section{HASIL DAN PEMBAHASAN}

Penelitian ini dilaksanakan selama tiga siklus dengan menerapkan enam langkah model pembelajaran Quantum Teaching yaitu: (1) tumbuhkan, (2) alami, (3) namai, (4) demonstrasikan, (5) ulangi, (6) rayakan.

Hasil observasi penerapan model pembelajaran Quantum Teaching terhadap guru dan siswa mengalami peningkatan pada setiap siklusnya hingga mencapai indikator kinerja penelitian yang ditargetkan yaitu $85 \%$.

a. Penerapan Model Quantum Taeching terhadap Guru dan Siswa

Perbandingan hasil observasi pada siklus I, II, dan III dapat dilihat pada tabel 1 sebagai berikut:

Tabel 1 Perbandingan Hasil Observasi Penerapan Model Quantum Teaching Terhadap Guru dan Siswa

\begin{tabular}{llll}
\hline \multirow{2}{*}{ Sumber Data } & \multicolumn{2}{l}{ Presentase (\%) } \\
\cline { 2 - 4 } & Siklus I & Siklus II & Siklus III \\
\hline Guru & 72,69 & 85,42 & 91,67 \\
Siswa & 72,11 & 84,84 & 90,51
\end{tabular}

Berdasarkan tabel 1 di atas dapat diketahui bahwa penerapan model quantum teaching terhadap guru pada siklus I mencapai rata-rata $72,69 \%$ kemudian meningkat pada siklus II menjadi $85,42 \%$ dan meningkat lagi pada siklus III menjadi $91,67 \%$. Hasil observasi penerapan model quantum teaching terhadap siswa pada siklus mencapai rata-rata $72,11 \%$ kemudian meningkat pada siklus II menjadi $84,84 \%$ dan meningkat pada siklus III menjadi 90,51\%. Jadi, dapat disimpulkan 
Volume 7 Nomor 2 Tahun 2019

bahwa penerapan model quantum teaching terhadap guru dan siswa pada setiap siklus meningkat.

b. Motivasi Belajar Matematika

Perbandingan hasil observasi dan angket motivasi belajar matematika antar siklus disajikan dalam tabel 2 berikut:

Tabel 2 Perbandingan Hasil Observasi dan Angket Motivasi Belajar Matematika

\begin{tabular}{cllll}
\hline & & \multicolumn{3}{l}{ Siklus } \\
\cline { 3 - 5 } & & I & II & III \\
\hline Observas & $(\%)$ & 72,08 & 85,83 & 90,00 \\
Angket & $(\%)$ & 74,50 & 85,18 & 90,42 \\
\hline
\end{tabular}

Berdasarkan tabel 2 di atas, hasil observasi motivasi belajar matematika siswa pada siklus I mencapai presentase $72,08 \%$, pada siklus II meningkat menjadi $85,83 \%$, dan pada siklus III meningkat mejadi $90,51 \%$. Peningkatan hasil siklus I ke siklus II sebesar $13,75 \%$ sedangkan untuk siklus II ke siklus III meningkat sebesar $4,86 \%$. Hasil angket motivasi belajar matematika pada siklus I sebesar $74,50 \%$, pada siklus II sebesar 85,18\%, pada siklus III meningkat menjadi 90,42\%. Peningkatan siklus I ke siklus II sebesar 10,68\% sedangkan peningkatan siklus II ke siklus III sebesar $5,24 \%$. Berdasarkan hasil tersebut dapat diketahui bahwa terjadi peningkatan hasil pada setiap siklus. Hal ini mengindikasikan bahwa penerapan model quantum teaching dapat meningkatkan motivasi belajar matematika siswa kelas IV SD Negeri 2 Kertodeso tahun ajaran 2018/2019.

Pembelajaran dengan menerapkan model quantum teaching dilaksanakan sebanyak tiga siklus. Siklus I dan II terdiri dari 2 pertemuan sedangkan pada siklus II hanya terdiri dari 1 pertemuan. Penerapan model quantum teaching memiliki 7 langkah pokok yaitu tumbuhkan, alami, namai, demonstrasikan, ulangi, dan rayakan yang biasa disingkat menjadi TANDUR. Langkah pembelajaran tersebut sesuai dengan pendapat oleh DePorter, Reardon, dan Singer-Nourie (2011: 39-40) yakni (1) tumbuhkan, yaitu memberi tahu siswa tentang manfaat mempelajari materi, (2) alami, yaitu menciptakan dan mendatangkan pengalaman secara umum dalam belajar, (3) namai yaitu dengan menyediakan kata kunci, model, konsep, strategi, rumus, sebuah "masukan', (4) demonstrasikan, yaitu memberikan kesempatan untuk siswa menunujukkan apa yang mereka ketahui, (5) ulangi, yaitu mengulang materi dan (7) rayakan yaitu dengan cara memberi pengakuan partisipasi, dan penghargaan untuk siswa. Penerapan model quantum teaching yang meliputi langkah TANDUR terbukti dapat meningkatkan pembelajaran. Berdasarkan hasil observasi penerapan model quantum teaching terhadap guru dan siswa maka dapat diketahui bahwa telah terjadi peningkatan dari siklus I sampai siklus III. Rata-rata hasil observasi penerapan model quantum teaching terhadap guru pada siklus I adalah 72,69\%, kemudian pada siklus II menjadi $85,42 \%$, dan pada siklus III meningkat menjadi $91,67 \%$. Hasil observasi penerapan model quantum teaching terhadap siswa pada sikus I mencapai rata-rata $72,11 \%$, meningkat pada siklus II menjadi $84,84 \%$, dan meningakat lagi pada siklus III menjadi $90,51 \%$. Hal tersebut dapat disimpulkan bahwa penerapan model quantum teaching dapat meningkatkan pembelajaran matematika kelas IV SD Negeri 2 Kertodeso tahun ajaran 2018/2019.

Berdasarkan analisis peneliti mengenai penerapan model quantum teaching yang dilaksanakan sesuai dengan langkah-langkah pembelajarannya selama tiga siklus, dapat diketahui bahwa motivasi belajar matematika siswa meningkat. Hal ini dibuktikan dengan rata-rata hasil observasi dan angket motivasi belajar siswa meningkat pada setiap siklusnya. Rata-rata hasil observasi motivasi belajar siswa pada siklus I adalah $72,08 \%$, kemudaian pada siklus II menjadi $85,83 \%$, dan pada siklus III menjadi 
$90,51 \%$. Angket motvasi belajar pada siklus I mencapai rata-rata $74,50 \%$, pada siklus II rata-ratanya naik menjadi $85,15 \%$, dan pada siklus III rata-ratanya naik lagi menjadi $90,42 \%$. Jadi, dapat disimpulkan bahwa penerapan model pembelajaran quantum teaching dapat meningkatkan motivasi belajar matematika siswa kelas IV SD Negeri 2 Kertodeso. Hal ini sesuai dengan penelitian yang dilakukan oleh Pebriana (2017: 73) yang berjudul "Penerapan Model Pembelajaran Quantum Teaching untuk Meningkatkan Motivasi Belajar Matematika Siswa Kelas V SDN 009 Bangkinang" bahwa model quantum teaching dapat meningkatkan motivasi belajar matematika siswa.

\section{SIMPULAN}

Berdasarkan deskripsi pelaksanaan penelitian yang dilakukan dalam tiga siklus dapat diambil kesimpulan sebagai berikut:

1. Langkah-langakah penerapan model Quantum Teaching dalam peningkatan motivasi belajar matematika siswa kelas IV SD Negeri 2 Kertodeso tahun ajaran 2018/2019 yaitu (1) tumbuhkan, (2) alami, (3) namai, (4) demonstrasikan, (5) ulangi, dan (6) rayakan.

2. Penerapan model Quantum Teaching dapat meningkatakan motivasi belajar matematika siswa kelas IV SD Negeri 2 Kertodeso. Pernyataan tersebut dibuktikan adanya peningkatan rata-rata hasil observasi dan angket motivasi pada setiap siklusmya. Rata-rata hasil observasi motivasi pada siklus I yaitu $72,08 \%$, kemudian meningkat pada siklus II menjadi $85,33 \%$, dan meningkat lagi pada siklus III menjadi $90,51 \%$. Rata-rata hasil angket motivasi siswa pada siklus I adalah $74,50 \%$, pada siklus II menjadi $85,18 \%$, dan pada siklus III menjadi $90,42 \%$. Hal ini sesuai dengan hasil penelitian yang dilakukan oleh Pebriana (2017: 64-73) yang menyatakan bahwa penerapan model Quantum Teaching dapat meningkatkan motivasi belajar matematika.

\section{DAFTAR PUSTAKA}

Arikunto, S. (2013). Prosedur Penelitian: Praktik. Jakarta: Rineka Cipta.

DePorter, B., Reardon dan Singer-Nourie (2011). Quantum Teaching: Mempraktikan Quantum Learning di Ruang-ruang Kelas. Bandung: Kaifa.

Nurhartiningrum, E. S. \& Zuli R. W. (2018). Penerapan Teknik Ice Breaking untuk Meningkatkan Aktivitas dan Hasil Belajar Siswa Kelas VII Materi Bilangan Bulat. Prosiding Seminar Nasional Hasil Penelitian Pendidikan dan Pembelajaran "Pengembangan Pembelajaran Inovatif dan Inspiratif: Menjawab Tantangan Era Milenial", 4 (1), 393-402.

Pebriana, P. H. (2017). Penerapan Model Pembelajaran Quantum Teaching untuk Meningkatkan Motivasi Belajar Matematika Siswa Kelas V SDN 009 Bangkinang. Journal Cendekia: Jurnal Pendidikan Matematika, 1 (2), 64-73.

Rusman. (2014). Model-model Pembelajaran Mengembangkan Profesionalisme Guru. Jakarta: PT Rajagrafindo Persada.

Sugiyono. (2013). Metode Penelitian Pendidikan: Pendekatan Kuantitatif Kualitatif dan $R \& D$. Bandung: Alfabeta.

Sunarto. (2012). Icebreaker dalam Pembelajaram Aktif. Surakarta: Cakrawala Media. 